\title{
PENGARUH BASIS CARBOPOL TERHADAP FORMULASI SEDIAAN GEL DARI EKSTRAK DAUN KATUK (Sauropus androgynus (L.) Merr)
}

\author{
Sheila Meitania Utami, Qisthy Laurany \\ Sekolah Tinggi Ilmu Kesehatan Kharisma Persada \\ Tangerang Selatan, 15417, Indonesia \\ E-mail: sheila.meitania@gmail.com
}

\begin{abstract}
ABSTRAK
Telah dilakukan penelitian pengaruh basis carbopol terhadap formulasi sediaan gel dari ekstrak daun katuk (Sauropus androgynus (L.) Merr). Penelitian ini bertujuan untuk membuat formulasi dan menentukan konsentrasi carbopol sebagai basis yang dapat menghasilkan sediaan gel yang baik. Penelitian ini menggunakan 3 formulasi gel, dengan variasi konsentrasi carbopol 2\%, 3,5\% dan 4\%. Evaluasi yang dilakukan meliputi uji organoleptis, homogenitas, $\mathrm{pH}$, dan daya sebar. Hasil pengamatan organoleptis pada formulasi I, II, dan III tidak mengalami perubahan pada bau dan warna, tetapi terdapat perbedaan pada bentuk dimana pada formulasi I berbentuk kental, formulasi II berbentuk kental, dan formulasi III bentuk kental agak kaku. Hasil pengamatan homogenitas pada formulasi I, II dan III tidak terlihat adanya partikel kasar pada kaca objek. Hasil pengukuran $\mathrm{pH}$ pada formulasi I, II, dan III tidak terjadi perubahan $\mathrm{pH}$ yang signifikan yaitu pada formulasi I 5,61; formulasi II 5,42 dan formulasi III 5,61. Hasil pengukuran daya sebar pada formulasi I, II, dan III tidak mencapai persyaratan daya sebar karena memiliki rata-rata daya sebar berkisar 2,05 $\mathrm{cm}$ sampai 4,05 cm. Kesimpulan formulasi I sediaan gel dari ekstrak daun katuk dengan konsentrasi basis carbopol sebanyak $2 \%$ memiliki evaluasi yang paling baik.
\end{abstract}

Kata Kunci: Carbopol, Sauropus androgynus, Gel, Basis, Formulasi

\section{ABSTRACT}

Carbopol research has been studied on gel formulation from katuk leaf extract (Sauropus androgynus (L.) Merr). This study aims to make formulations and determine the concentration of carbopol as a base that can produce a good gel preparation. This research used 3 gel formulations, with variation of carbopol 2\%, 3,5\% and 4\% concentration. The result of organoleptic observations in formulations I, II, and III have not changed in odor and color, but there are differences in the form in which formulation I form is thick, formulation II is viscous, and formulation III viscous form is rather stiff. The result of homogenity observation on formulation I, II and III did not show any coarse particles on the glass object. The results of pH measurements in formulations I, II, and III did not change significantly $p H$ that is in the formulation I 5,61; formulation II 5,42 and formulation III 5,61. The result of the measurement of the scattering power in the formulations I, II, and III did not reach the scattering power requirement because it has an average power range of 2,05 cm to 4,05 cm. The conclusions of formulation I by gel preparation from katuk leaf extract with $2 \%$ of carbopol base concentration had the best evaluation.

Keywords: Carbopol, Sauropus androgynus, Gel, Base, Formulation 


\section{PENDAHULUAN}

Akhir-akhir ini banyak dikembangkan penelitian yang berfokus pada bahan alam, termasuk penelitian di bidang industri kosmetik. Manfaat bahan alam yang dapat diambil antara lain sifat antioksidannya yang dapat menghambat radikal bebas sehingga antioksidan digunakan untuk mencegah penuaan dini. Antioksidan alami umumnya terdapat pada sayur-sayuran, buah-buahan, umbiumbian dan kacang-kacangan (Elsner, P. dan Howard, 2000).

Daun katuk termasuk ke dalam famili Euphorbiaceae, yang dikenal di daerah dengan nama tarok manis, atau cekok manis, babing, kertu, dan dalam bahasa asing dikenal dengan nama sweet shoot (Malik, 1997). Katuk (Sauropus androgynus (L.) Merr) merupakan tanaman obat-obatan tradisional yang mempunyai zat gizi tinggi sebagai antibakteri, dan mengandung beta karoten sebagai zat aktif warna kakas. Daun katuk dapat bekerja sebagai antioksidan yang disebabkan adanya senyawa golongan fenol yaitu flavonoid (Ida, 2013).

Hasil penelitian Kelompok Kerja Nasional Tumbuhan Obat Indonesia menunjukkan bahwa tanaman katuk (Sauropus androgynus (L.) Merr) mengandung beberapa senyawa kimia, antara lain alkaloid papaverin, protein, lemak, mineral, saponin, flavonoid dan tanin (Rukmana, 2003). Kemampuan flavonoid sebagai antioksidan telah banyak diteliti belakangan tahun ini, dimana flavonoid memiliki kemampuan untuk merubah atau mereduksi radikal bebas dan juga sebagai anti radikal bebas. Nilai $\mathrm{IC}_{50}$ yang diperoleh sebesar 80,81 , hal ini berarti bahwa flavonoid dari daun katuk (Sauropus androgynus (L.) Merr) memiliki kemampuan sebagai antioksidan yang kuat (Giorgio, 2000).

Sediaan gel aplikasinya ditujukan untuk kulit atau pada permukaan kulit untuk aksi lokal. Sediaan gel memiliki sifat fisik (karakteristik utama yang mempengaruhi gel meliputi daya sebar, maupun $\mathrm{pH}$ ) dan stabilitas (kemampuan gel bertahan pada parameter sifat fisiknya untuk beberapa periode waktu) yang lebih baik aplikasinya jika dibandingkan dengan sediaan krim dan salep (Kaur dan Guleri, 2013). Sediaan gel mempunyai kadar air yang tinggi, sehingga dapat menghidrasi permukaan kulit teratas (stratum corneum) dan mengurangi resiko timbulnya peradangan lebih lanjut akibat menumpuknya minyak pada pori-pori. Daya lekat gel sangat lama karena terdiri sebagian besar airserta hampir tidak adanya sediaan padat didalamnya sehingga mudah diserap (Ansel, 1989). 
Carbopol merupakan bahan pembentuk gel yang sempurna. Dapat membentuk gel dengan baik dan juga menambah viskositas. Carbopol digunakan dalam formulasi sediaan farmasi dan kosmetik sebagai pengemulsi, pensuspensi, peningkat viskositas dalam sediaan krim; gel; dan ointment untuk penggunaan ophthalmic, rektal dan topikal. Penggunaannya relatif aman karena tidak ada toksik dan tidak mengiritasi serta tidak mengakibatkan reaksi hipersensitivitas pada penggunaan topikal (Rowe, dkk, 2006).

Berdasarkan penelitian diatas, penulis tertarik untuk melakukan penelitian yang berjudul "pengaruh basis carbopol terhadap formulasi sediaan gel dari ekstrak daun katuk (Sauropus androgynus (L.) Merr)" sebagai alternatif untuk mengatasi masalah tersebut.

\section{METODE}

\section{Alat dan Bahan}

Instrumen penelitian yang digunakan adalah alat-alat laboratrium seperti mortir, stamper, gelas beaker, $\mathrm{pH}$ meter, timbangan analitik, kaca arloji, kaca preparat, spatel, waterbath, dan wadah sediaan gel. Bahan yang digunakan adalah daun katuk, carbopol, propilenglikol, metil paraben, propil paraben, aquadest, dan etanol $70 \%$.

\section{Pembuatan Ekstrak}

Sebanyak 300 gram serbuk simplisia daun Sauropus androgynus dimasukkan ke dalam wadah kaca, kemudian direndam dengan larutan etanol $70 \%$ sebanyak 2L, ditutup dengan aluminium foil dan dibiarkan selama 5 hari sambil sesekali diaduk. Setelah 5 hari, sampel yang direndam tersebut disaring menggunakan kertas saring menghasilkan filtrat 1 dan ampas 1 . Ampas yang ada kemudian ditambah dengan larutan etanol 70\% sebanyak 1L, ditutup dengan aluminium foil dan dibiarkan selama 2 hari sambil sesekali diaduk. Setelah 2 hari, sampel tersebut disaring menggunakan kertas saring lalu menghasilkan filtrat 2 dan ampas 2 . Filtrat 1 dan 2 digabung menjadi satu lalu dievaporasi menggunakan waterbath, sehingga diperoleh ekstrak kental kemudian dibiarkan pada suhu ruang hingga seluruh pelarut etanol menguap.

\section{Formulasi Gel}

Formulasi ekstrak daun katuk dengan pengaruh basis carbopol sebagai gelling agent menjadi bentuk sediaan gel terdiri dari gelling agent berupa carbopol pada berbagai tingkat konsentrasi yaitu $2 \%$ (FI), 3,5\% (FII), dan 4\% (FIII) serta zat tambahan. 
Tabel 1. Formulasi Sediaan Gel

\begin{tabular}{lllll}
\hline \multirow{2}{*}{ Bahan } & \multicolumn{3}{c}{ Formula (b/b) } & \multirow{2}{*}{ Fungsi } \\
\cline { 2 - 4 } & F I & F II & F III & \\
\hline Ekstrak Daun Katuk & $1 \%$ & $1 \%$ & $1 \%$ & Zat Aktif \\
Carbopol & $2 \%$ & $3,5 \%$ & $4 \%$ & Gelling Agent \\
Propilenglikol & $15 \%$ & $15 \%$ & $15 \%$ & Humektan \\
Metil Paraben & $0,1 \%$ & $0,1 \%$ & $0,1 \%$ & Pengawet \\
Propil Paraben & $0,025 \%$ & $0,025 \%$ & $0,025 \%$ & Pengawet \\
Aquadest & $24,5 \% \%$ & $24,05 \%$ & $23,9 \%$ & Pelarut \\
\hline
\end{tabular}

Keterangan :

F I = Formula I sediaan gel dengan basis carbopol konsentrasi $2 \%$

$\mathrm{F}$ II = Formula II sediaan gel dengan basis carbopol konsentrasi 3,5\%

F III = Formula III sediaan gel dengan basis carbopol konsentrasi 4\%

\section{Evaluasi Sediaan Gel}

\section{Uji Organoleptis}

Gel yang mengandung berbagai konsentrasi carbopol dilakukan pengamatan secara visual terhadap sediaan gel yang didapatkan meliputi bau, warna dan bentuk dari sediaan gel.

Uji Homogenitas Gel yang mengandung berbagai konsentrasi carbopol sebanyak 0,1 g dioleskan pada kaca objek yang telah bersih hingga membentuk lapisan tipis, tutup kaca objek menggunakan kaca preparat

\section{Uji pH}

Gel yang mengandung berbagai konsentrasi carbopol sebanyak $1 \mathrm{~g}$ dilarutkan dalam $100 \mathrm{~mL}$ air aquadest dan diukur masing-masing $\mathrm{pH}$ nya dengan menggunakan $\mathrm{pH}$ meter.

\section{Uji Daya Sebar}

Gel yang mengandung berbagai konsentrasi carbopol sebanyak $0,5 \mathrm{~g}$ diletakkan di atas kaca bulat, kemudian kaca lain diletakkan di atasnya dan dibiarkan selama 1 menit, lalu diameter sebar gel diukur. Setelah itu ditambahkan150 g beban dan didiamkan selama 1 menit lalu diukur diameter yang konstan.

\section{HASIL}

Berdasarkan Tabel 1, Formulasi sediaan gel dengan 3 variasi konsentrasi carbopol yang digunakan pada formula I ekstrak daun katuk 1\%, carbopol 2\%, propilenglikol $15 \%$, metil paraben $0,1 \%$, propil paraben $0,25 \%$, aquadest $24,5 \%$; pada formula II ekstrak daun katuk 1\%, carbopol 3,5\%, propilenglikol 15\%, metil paraben $0,1 \%$, propil paraben $0,25 \%$, aquadest $24,05 \%$; dan pada formula III ekstrak daun katuk 1\%, carbopol 4\%, 
Tabel 2. Hasil Pengamatan Uji Organoleptis Sediaan Gel

\begin{tabular}{cccccc}
\hline Formulasi & Organoleptis & \multicolumn{4}{c}{ Minggu ke- } \\
\cline { 2 - 5 } & & $\mathbf{0}$ & $\mathbf{1}$ & $\mathbf{2}$ & $\mathbf{3}$ \\
\cline { 2 - 5 } F I & Bau & Khas & Khas & Khas & Khas \\
& Bentuk & Kental & Kental & Kental & Kental \\
& Warna & $\begin{array}{c}\text { Coklat } \\
\text { kehijauan }\end{array}$ & $\begin{array}{c}\text { Coklat } \\
\text { kehijauan }\end{array}$ & $\begin{array}{c}\text { Coklat } \\
\text { kehijauan }\end{array}$ & $\begin{array}{c}\text { Coklat } \\
\text { kehijauan }\end{array}$ \\
\hline \multirow{2}{*}{ F II } & Bau & Khas & Khas & Khas & Khas \\
& Bentuk & Kental & Kental & Kental & Kental \\
& Warna & Coklat & Coklat & Coklat & Coklat \\
& & kehijauan & kehijauan & kehijauan & kehijauan \\
\hline F III & Bau & Khas & Khas & Khas & Khas \\
& Bentuk & Kental & Kental agak & Kental agak & Kental agak \\
& Warna & Coklat & kaku & kaku & kaku \\
& & kehijauan & Coklat & Coklat & Coklat \\
& & & kehijauan & kehijauan & kehijauan \\
\hline
\end{tabular}

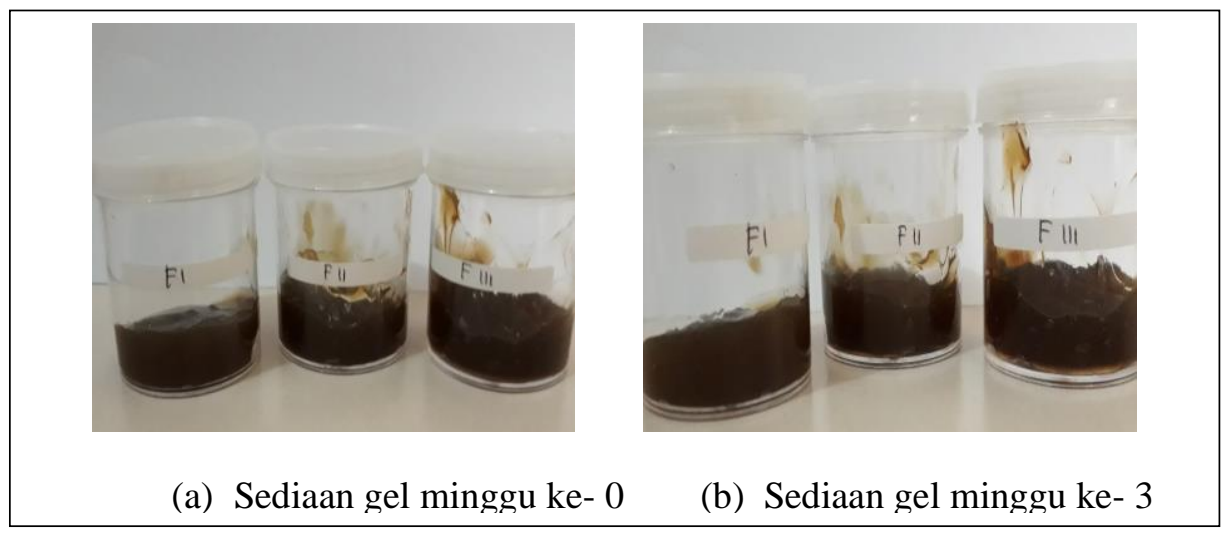

Gambar 1. Hasil Pengamatan Uji Organoleptis Sediaan Gel

Berdasarkan Gambar 1 dan Tabel 2 Hasil pengamatan uji organoleptis sediaan gel yang dilakukan selama 3 minggu penyimpanan pada suhu kamar. Pada minggu ke-0 yaitu pada formulasi I (F I) sediaan kental, berwarna coklat kehijauan, berbau khas; pada formulasi II (F II) sediaan kental, berwarna coklat kehijauan, berbau khas; pada formula III (F III) sediaan kental, berwarna coklat kehijauan, berbau khas.

Pada minggu ke-1 pada formulasi I (F I) sediaan kental, berwarna coklat kehijauan, berbau khas; pada formulasi II (F II) sediaan kental, berwarna coklat kehijauan, berbau khas; pada formulasi III (F III) sediaan kental agak kaku, berwarna coklat kehijauan, berbau khas. 
Pada minggu ke-2 pada formulasi I (F I) sediaan kental, berwarna coklat kehijauan, berbau khas; pada formulasi II (F II) sediaan kental, berwarna coklat kehijauan, berbau khas, dan pada formulasi III (F III) sediaan kental agak kaku, berwarna coklat kehijauan, berbau khas.
Pada minggu ke-3 pada formulasi I (F I) sediaan kental, berwarna coklat kehijauan, berbau khas; pada formulasi II (F II) sediaan kental, berwarna coklat kehijauan, berbau khas; pada formulasi III (F III) sediaan kental agak kaku, berwarna coklat kehijauan, berbau khas.

Tabel 3. Hasil Pengamatan Uji Homogenitas Sediaan Gel

\begin{tabular}{ccccc}
\hline Formulasi & \multicolumn{4}{c}{ Minggu ke- } \\
\cline { 2 - 5 } & $\mathbf{0}$ & $\mathbf{1}$ & $\mathbf{2}$ & $\mathbf{3}$ \\
\hline F I & Homogen & Homogen & Homogen & Homogen \\
\hline F II & Homogen & Homogen & Homogen & Homogen \\
\hline F III & Homogen & Homogen & Homogen & Homogen \\
\hline
\end{tabular}

Berdasarkan Tabel 3 Hasil adanya partikel kasar pada kaca objek, pengamatan uji homogenitas sediaan gel maka pada ketiga formulasi sediaan gel yaitu pada minggu ke-0 sampai minggu dinyatakan homogen.

ke-3 menunjukkan bahwa tidak terlihat

Tabel 4. Hasil Pengukuran Rata-rata Nilai Uji pH Sediaan Gel

\begin{tabular}{cccc}
\hline Minggu ke- & $\begin{array}{c}\text { Formulasi I } \\
\text { (F I) }\end{array}$ & $\begin{array}{c}\text { Formulasi II } \\
\text { (F II) }\end{array}$ & $\begin{array}{c}\text { Formulasi III } \\
\text { (F III) }\end{array}$ \\
\hline 0 & 5,58 & 4,71 & 5,69 \\
1 & 5,28 & 5,37 & 5,51 \\
2 & 6,40 & 6,12 & 6,08 \\
3 & 5,21 & 5,51 & 5,19 \\
\hline Rata-rata & $\mathbf{5 , 6 1}$ & $\mathbf{5 , 4 2}$ & $\mathbf{5 , 6 1}$ \\
\hline
\end{tabular}

Berdasarkan Tabel 4, Hasil pengukuran uji $\mathrm{pH}$ sediaan gel dari ekstrak daun katuk dengan 3 variasi konsentrasi carbopol selama 3 minggu penyimpanan pada suhu kamar terdapat sampel formulasi I (F I), formulasi II (F II) dan formulasi III (F III) berturut-turut menunjukkan nilai $\mathrm{pH}$ masing-masing sebagai berikut: minggu ke-0 yaitu 5,58; 4,62 dan 5,69, minggu ke-1 yaitu 5,28; 5,37 dan 5,51, minggu ke-2 yaitu 5,28; 5,37 dan 5,51. Pada minggu ke-2 yaitu 6,$40 ; 6,12$; dan 6,08. Pada minggu ke-3 yaitu 5,$21 ; 5,51$ dan 5,19. Maka nilai rata- 
rata $\mathrm{pH}$ ketiga formulasi selama 3 yaitu 5,34.

minggu, penyimpanan pada suhu kamar

Tabel 5. Hasil Pengukuran Daya Sebar Sediaan Gel

\begin{tabular}{cccc}
\hline Beban Berat & Formulasi I (F & Formulasi II (F & Formulasi III (F \\
& I) & II) & III) \\
\hline 0 gram & Tinggi $: 3,2 \mathrm{~cm}$ & Tinggi $: 2,1 \mathrm{~cm}$ & Tinggi $: 2 \mathrm{~cm}$ \\
& Lebar $: 3,3 \mathrm{~cm}$ & Lebar $: 2,2 \mathrm{~cm}$ & Lebar $: 2,1 \mathrm{~cm}$ \\
\hline Rata-rata & $\mathbf{3 , 2 5} \mathbf{~ c m}$ & $\mathbf{2 , 1 5} \mathbf{~ c m}$ & $\mathbf{2 , 0 5} \mathbf{~ c m}$ \\
\hline 150 gram & Tinggi $: 4,3 \mathrm{~cm}$ & Tinggi $: 2,1 \mathrm{~cm}$ & Tinggi $: 2,1 \mathrm{~cm}$ \\
& Lebar $: 4,2 \mathrm{~cm}$ & Lebar $: 2,5 \mathrm{~cm}$ & Lebar : $2,6 \mathrm{~cm}$ \\
\hline Rata-rata & $\mathbf{4 , 2 5} \mathbf{~ c m}$ & $\mathbf{2 , 3} \mathbf{~ c m}$ & $\mathbf{2 , 3 5} \mathbf{~ c m}$ \\
\hline
\end{tabular}

Berdasarkan Tabel 5 Hasil pengukuran daya sebar sediaan gel dari ekstrak daun katuk dengan 3 variasi konsentrasi carbopol selama 3 minggu penyimpanan pada suhu kamar terhadap sampel formula I (F I), formula II (F II) dan formula III (F III) berturut-turut menunjukkan bahwa daya sebar masingmasing sebagai berikut: pada formulasi I (F I) dengan beban berat $0 \mathrm{~g}$ memiliki tinggi gel $3,2 \mathrm{~cm}$, dan lebar gel $3,3 \mathrm{~cm}$, sedangkan beban berat $150 \mathrm{~g}$ dengan tinggi gel memiliki $4,3 \mathrm{~cm}$, dan lebar gel $4,2 \mathrm{~cm}$. Pada formulasi II (F II) dengan beban berat $0 \mathrm{~g}$ memiliki tinggi gel 2,1 $\mathrm{cm}$, dan lebar gel sebesar 2,2 $\mathrm{cm}$, sedangkan beban berat $150 \mathrm{~g}$ diperoleh tinggi gel 2,1 cm, dan lebar gel sebesar 2,5 cm. Pada formulasi III (F III) dengan beban berat $0 \mathrm{~g}$ memiliki tinggi gel $2 \mathrm{~cm}$, dan lebar gel 2,1 cm, sedangkan beban berat $150 \mathrm{~g}$ diperoleh tinggi gel $2,1 \mathrm{~cm}$, dan lebar gel 2,6 cm. Maka hasil pengukuran rata-rata daya sebar pada formulasi I (F I) dengan beban berat $0 \mathrm{~g}$ yaitu $3,25 \mathrm{~cm}$, beban berat $150 \mathrm{~g}$ yaitu $4,25 \mathrm{~cm}$. Pada formulasi II (FII) dengan beban berat $0 \mathrm{~g}$ yaitu $2,15 \mathrm{~cm}$, beban 150 g yaitu 2,3 cm. Pada formulasi III (F III) dengan beban berat $0 \mathrm{~g}$ yaitu $2,05 \mathrm{~cm}$, beban berat $150 \mathrm{~g}$ yaitu $2,35 \mathrm{~cm}$.

\section{DISKUSI}

Pada penelitian ini formulasi sediaan gel menggunakan ekstrak daun katuk sebagai zat aktif. . Simplisia daun katuk diperoleh dari Pasar Bukit, Pamulang. Sebanyak 300 g serbuk simplisia daun Sauropus androgynus diekstraksi dengan metode maserasi dan menggunakan penyari etanol $70 \%$.

Menggunakan metode maserasi bertujuan untuk menarik zat-zat berkhasiat yang tidak tahan terhadap 
pemanasan dengan pengerjaan dan peralatan yang digunakan sangat sederhana (Dirjen POM, 2000). Ekstraksi dengan menggnakan penyari etanol $70 \%$ karena penyari etanol merupakan penyari yang sangat baik karena dapat mengekstrasi senyawa polar maupun non polar (Rowe, dkk, 2009). Etanol yang digunakan sebanyak $3 \mathrm{~L}$ dan menghasilkan ekstrak kental seberat $124,93 \mathrm{~g}$.

Formulasi sediaan gel dibuat menjadi 3 variasi konsentrasi carbopol. Tujuan dilakukannya perbedaan konsentrasi carbopol untuk formulasi sediaan gel ini digunakan basis carbopol karena memiliki efektifitas yang tinggi dalam perannya untuk memberikan pembentukkan gel yang baik pada sediaan gel (Allen, 2002).

Carbopol dikembangkan terlebih dahulu ke dalam aquadest sebagai bahan pelarut dan medium pendispersi (Ansel, 1989) dan diaduk hingga terbentuk basis gel, kemudian ditambahkan metil paraben dan propil paraben (sebelumnya dilarutkan dengan etanol 70\%) sebagai pengawet antimikroba untuk sediaan kosmetik, makanan dan sediaan farmasi (Rowe, dkk, 2009).

Propilenglikol kemudian diaduk sampai homogen alasan digunakan propilenglikol karena berfungsi sebagai humektan, plasticizer, dan pelarut (Rowe, dkk, 2009).

Ekstrak daun katuk (sebelumnya dilarutkan dengan aquadest) dimasukkan kedalam basis gel tersebut dan diaduk hingga homogen. Sisa aquadest ditambahkan kembali dan diaduk hingga homogen. Sediaan gel yang didapat disimpan pada wadah yang tertutup rapat.

Pada penelitian ini dilakukan uji organoleptis pada formulasi sediaan gel ekstrak daun katuk dengan variasi konsentrasi carbopol sebanyak 2\%, 3,5\% dan $4 \%$ yang bertujuan untuk mengetahui perubahan warna, bentuk dan bau selama penyimpanan (Ansel, 1998). Selama 3 minggu penyimpanan pada suhu kamar menunjukkan bahwa ketiga formula tersebut tidak mengalami perubahan bau dan warna yaitu sediaan memiliki bau khas daun katuk dan berwarna coklat kehijauan. Sedangkan bentuk pada ketiga formulasi terdapat perbedaan dimana formula I (F I) berbentuk kental, formulasi II (F II) berbentuk kental, dan formulasi III berbentuk kental agak kaku.

Pada penelitian ini dilakukan uji homogenitas pada sediaan gel dari ekstrak daun katuk yang mengandung 3 variasi konsentrasi carbopol yang bertujuan untuk melihat sediaan gel homogen atau tidak. Homogenitas sediaan ditunjukkan dengan ada tidaknya butiran kasar (Dirjen POM, 1995). Hasil pengamatan uji 
homogenitas selama 3 minggu penyimpanan pada suhu kamar sediaan gel dari ekstrak daun katuk memiliki homogenitas yang baik karena tidak terlihat adanya partikel kasar pada kaca objek, maka pada ketiga formulasi sediaan gel dari variasi konsentrasi carbopol dinyatakan homogen.

Pada penelitian ini dilakukan uji $\mathrm{pH}$ pada formulasi sediaan gel ekstrak daun katuk untuk mengetahui derajat keasaman dari sediaan gel yang dihasilkan (Draelos dan Lauren, 2006). Pada formula I, formula II dan formula III menunjukkan bahwa tidak terjadinya perubahan $\mathrm{pH}$ yang signifikan selama 3 minggu penyimpanan pada suhu kamar dan diperoleh rata-rata nilai sediaan yaitu berkisar antara 5,34. Menurut Martin (1983) mengenai uji pH sediaan gel memenuhi persyaratan uji $\mathrm{pH}$ yaitu berkisar 4,5-6,5.

Pada penelitian ini dilakukan uji daya sebar pada formulasi sediaaan gel ekstrak daun katuk dengan variasi konsentrasi carbopol yang bertujuan untuk mengetahui kemampuan penyebaran sediaan gel yang dihasilkan pada tempat aplikasi (Garg, dkk, 2002). Menurut penelitian Astuti dkk (2010) penelitian sebelumnya uji daya sebar, formulasi sediaan gel memiliki daya sebar yang baik sudah sesuai dengan syarat daya sebar yaitu 5-7 cm (Garg, dkk,
2002). Sedangkan daya sebar pada sediaan gel dari ekstrak daun katuk dari ketiga variasi carbopol diperoleh daya sebar berkisar 2,05-4,25 $\mathrm{cm}$, maka sediaan gel yang dihasilkan tidak memenuhi syarat nilai sebar. Hasil untuk uji daya sebar menunjukkan bahwa sediaan gel dari ekstrak daun katuk memiliki daya sebar yang tidak sesuai dengan syarat nilai sebar yaitu $5-7 \mathrm{~cm}$ (Garg, 2002) hal tersebut ditandai dengan semakin tinggi konsentrasi carbopol yang digunakan maka semakin menurun daya sebar yang dihasilkan.

\section{SIMPULAN}

Formulasi sediaan gel dari ekstrak daun katuk dengan 3 variasi konsentrasi carbopol yaitu formulasi I sebanyak 2\%, formulasi II sebanyak 3,5\% dan formulasi III sebanyak $4 \%$.

Hasil pengamatan organoleptis pada formulasi I, II, dan III tidak mengalami perubahan pada bau dan warna, tetapi terdapat perbedaan pada bentuk dimana pada formulasi I berbentuk kental, formulasi II berbentuk kental, dan formulasi III bentuk kental agak kaku.

Hasil pengamatan homogenitas pada formulasi I, II dan III tidak terlihat adanya partikel kasar pada kaca objek.

Hasil pengukuran pH pada formulasi I, II, dan III tidak terjadi perubahan $\mathrm{pH}$ yang signifikan yaitu pada 
formulasi I 5,61; formulasi II 5,42 dan formulasi III 5,61.

Formulasi Formulasi I sediaan gel dari ekstrak daun katuk dengan konsentrasi basis carbopol sebanyak $2 \%$ memiliki evaluasi yang paling baik.

\section{DAFTAR PUSTAKA}

Ajit B. Patil, Asha S. Jadhav, Flavonoid an Antioxidant : A Review, Internasional Journal of Pharmaceutical and Biological Sciences Research and Devlopment, IJPBSRD 1 (2), Oktober 2013 : hal. 07-20.

Allen, L. V., 2002, The Art, Science and Technology of Pharmaceutical Compounding, Second Edition, 170-173, 183, 187, American Pharmaceutical Association, Washington D.C.

Amrun, H.M., Umiyah \& Evi Umiyah U., 2007. "Uji Aktivitas Antioksidan Ekstrak Air dan Ekstrak Air dan Ekstrak Metanol Beberapa Varian Buah Kenitu (Chrysophyllum cainiti L) dari Daerah Jember. Berk.Panel.Hayati. 13:45-50.

Ansel, H.C., 1989, Pengantar Bentuk Sediaan Farmasi, diterjemahkan oleh Farida Ibrahim, Asmanizar, Iis Aisyah, Edisi keempat, 255-271, 607608, 700, Jakarta, UI Press.

Anwar, Effionora. 2012., Eksipien Dalam Sediaan Farmasi. Jakarta : Dian rakyat.

Astuti, Y., B. Wahjoedi dan M.W. Winarno., 1997. Efek diuretik infus akar katuk terhadap tikus putih. Warta Tumbuhan Obat 3 (3): 42-43.

Astuti, dkk., 2010. Accounting Guidance. Bandung : CV Accounting.
Barry, B. W., 1983, Dermatological Formulation, Marcell Dekker Inc, New York, pp. 52-53.

BPOM., 2008. Informatorium Obat Nasional Indonesia. Badan Pengawas Obat dan Makanan Republik Indonesia. Jakarta.

Depkes RI, 1995. Farmakope Indonesia. Edisi V. Jakarta: Departemen Kesehatan Republik Indonesia. Pp 6.

Draelos, Z. D., dan Lauren A. Thaman, 2006. Cosmetic Formulation of Skin Care Product. New York: Taylor and Francis Group. Hal. 11.

Dirjen POM., 1995. Farmakope Indonesia Edisi IV. Jakarta: Departemen Kesehatan RI.

Dirjen POM, 2000, Parameter Standar Umum Ekstrak Tumbuhan Obat. Cetakan Pertama. Jakarta: Departemen Kesehatan RI. Halaman 3-5, 10-11.

Elsner, P. \& Howard I.M., 2000, Cosmeceuticals drug vs Cosmetics. Marcel Dekker Inc. New York: 16, 145, 163.

Ermelinda, N., B. Yohanes, dan D. C. Theo, 2013. Isolasi, identifikasi dan uji aktivitas senyawa antioksidan fraksi kloroform simplisia methanol sarang semut (Myrmecodia Pendens). Jurnal Kimia Terapan. Ed.1, No.1. pp 6-11.

Farnsworth, N. R., 1996. Biological and Phytochemial Screening of Plants. J. Pharm. Sci 55.

Galuh Puspitasari, Sri Murwani, Herawati., 2012. Uji Daya Hambat Antibakteri Perasan Buah Mengkudu Matang (Morinda citrifolia) terhadap bakteri MRSA secara in vitro.

Garg, A., Anggarwal, D., Garg , S., dan Singla, A.K, 2002, Spreading of Semisolid Formulation : An Update, $\quad$ Pharmaceutical Technology, USA, pp. 84-104. 
Giorgio, P., 2000, Flavonoid an Antioxidant. Journal National Product.

63. 1035-1045.

Hermawaty, R., 2014. Khasiat ajaib sarang semut berantas berbagai penyakit. Padi. Jakarta.

Ida, C., dan Meona, S., 2013. Comparative In- Vitro Antioxsidant Study Of Three Species From Euphorbiaceae Family. Journal Departement of Pharmacognosy, Karpagam collage of pharmacy, Coimbatore-32, Tamil Nadu, India. Departement of Microbiology, Karpagam University, Coimbatore-32, Tamil Nadu, India. Vol.3 (2).

Kaur, L. P., and Guleri, T. K., 2013, Topikal Gel : A Recent Approach for Novel Drug Delivery, Asian Journal of Biomedical and Pharmaceutical Sciences, 3(17): 1-5.

Lachman, L., Lieberman, H. A., Kanig, J. L., 1994. Teori dan Praktek Farmasi Industri, edisi III, Diterjemahkan Oleh Suyatmi, S., Universitas Indonesia press, Jakarta.

Lachman, L., H.A. Lieberman, J.L. Kaning., 1989. Teori dan

Praktek Farmasi Industri. Jakarta: UI-Press.

Levin, J., Hiward, I, Maibach, 2001. Human skin buffering capacity:An Overview. New York : Marcel Dekker. Inc.

Mukul, S., Surabhi, K, dan Atul, N., 2011, Cosmeceutical for the Skin:an Overview, Asian Journal of Pharmaceutical and Clinical Research, 4(2):1.

Niazi, 2004, Handbook of Pharmaceutical Manufacturing Formulation, Liquid Products, volume 3, CRC Press, Boca
Lieberman, H.A., Rieger, M.M., dan Banker, G.S., (Eds), 1996, Pharmaceutical Dosage Form: Disperse System, Volume 1, $2^{\text {th }}$ ed., Marcel Dekker Inc., New York, hal. 57, 115.

Lieberman, A. H., Rieger, M. M., and Banker S. G., 1998, Pharmaceutical Dosage Forms: Disperse System, Volume 3, Second Edition, Revised and Expanded, 265267, 272-273, Marcel Dekker, Inc., New York.

Malik, A, 1997. Tinjauan fitokimia, indikasi penggunaan dan bioaktivitas daun katuk dan buah trengguli. Warta Tumbuhan Obat Indonesia 3 (3): 39.

Martin, A., Swarbick, J., dan A. Cammarata. 1993. Farmasi Fisik 2. Edisi III. Jakarta: UI Press. Pp. 940-1010, 1162, $1163,1170$.

Martin, A., Swarbrick, J., dan Cammart, A., 2012, Farmasi Fisik Dasar - Dasar Farmasi Fisik Dalam Ilmu Farmasetik, Penerbit Universitas Indonesia, Jakarta, pp. 1077.

Marliana, S.D., V. Suryanti., Suyono. 2005. Skrining Fitokimia dan Analisis Kromatografi Lapis Tipis Komponen Kimia Buah Labu Siam (Sechium edule Jacq. Swartz.) dalam Ekstrak Etanol. Biofarmasi. 3(1): 26-31.

Raton London New York Washington, D.C.

Puspaningtyas, D. M., Sutrisno, dan S. B. Susetyo. 1997. Usaha tani katuk di Desa Cilebut Barat Kabupaten Bogor. The Journal Indonesian Medicine Plants. 3 (3) : 9-10. 
Robinson, T., 1991. Kandungan Organik Tumbuhan Tingkat Tinggi. Bandung: Penerbit ITB.

Rowe, R.C., Sheskey, P.J., and Quinn, M.E., 2005. Handbook of Pharmaceutical Excipients, $5^{\text {th }}$ Edition. American Pharmaceutical Association : Pharmaceutical Press. Halaman 326-329.

Rowe, R.C., P.J. Sheskey, S.O. Owen, 2006, Handbook of Pharmaceutical Excipients, $5^{\text {th }}$ ed., Pharmaceutical Press, London, 465-469.

Rowe, R.C., Sheskey, P.J., Quinn, M.E., 2009, Handbook of Pharmaceutical Excipient, $6^{\text {th }}$ Edition, Pharmaceutical Press, London, pp. 110-113, 283-286, 592-594.

Rowe, R. C., Sheskey, P.L., Quinn, M. E., 2009 Handbook of Pharmaceutical Excipients, 6th edition, Pharmaceutical Press And American Pharmacists Association. USA, pp. 110-113, 441-445, 754-755.

Rukmana, H. R. \& I. M. Harahap. 2011. Katuk Potensi dan Manfaatnya. Penerbit Kanisius. Yogyakarta. [18 Mei 2011]

Rukmana, R. Dan Indra M.H., 2003, Katuk. Potensi dan Manfaatnya. Kanisus. Yogyakarta.

Santoso, H.B., 2008. Ragam dan Khasiat Tanaman Obat. Jakarta : Agromedia Pustaka. Cetakan I.

Sharma, S., 2008, Topical Drug Delivery System : a Review, Pharmaceut. Rev., 6, 1-29.
Singgih Santoso, 2009. Panduan Lengkap Menguasai Statistik Dengan SPSS 17. Jakarta: PT Elex Media Komputindo.

Syamsuni, 2005, Farmasetika Dasar dan Hitungan Farmasi, Buku kedokteran EGC, Jakarta.

Tiwari, P., Kumar, B., Kaur, M., Kaur G. \& Kaur H., 2011, Phytochemical Screening And Extraction: A Review, International Pharmaceutica Sciencia, 1, 1, 98-106.

Wathoni, Nasrul., Rusdiana, Taofik., dan R.Y. Hutagaol, 2009, Formulasi Gel Antioksidan Ekstrak Rimpang Lengkuas (Alpinia galangal L. Willd) dengan Menggunakan Basis Aqupec 505 HV. Jurnal Indonesia. Universitas Padjadjaran Bandung.

Zats , J. L., and Kushla, G. P., 1996 Gels, in Lieberman, HA., Lachman, L., Schwatz, JB., Pharmaceutical Dosage Form: Dysperse System, Vol. 2, 2nd edition, Marcell Dekker Inc, New York, pp. 399-417.

Zats, J.I., dan Gregory P.K., 1996, Gel in Lieberman, H.A., Rieger, M.M., Banker, G.S., Pharmaceutical Dosage Forms: Disperse System, Vol 2, 401403, 413-414, Marcel Dekker Inc, New York.

Zuhra, Cut Fatimah, dkk,. 2008. "Aktivitas Antioksidan Senyawa Flavonoid dari Daun Katuk (Sauopus androgunus (L) Merr)". Jurnal Biologi Sumatera Vol3 No 1. Hlm. 710, Januari 2008. 